\title{
Hubungan Pola Asuh Demokratis Dengan Perilaku Asertif Pada Remaja
}

\section{Correlation Of Democratic Parenting Patterns With Assertive Behavior In Adolescents}

\author{
Dian Permata Sari ${ }^{(1 *}$, Istiana ${ }^{(2)} \&$ Nini Sri Wahyuni(3) \\ Fakultas Psikologi, Universitas Medan Area, Indonesia \\ Disubmit: 19 Juli 2021; Diproses: 19 Juli 2021; Diaccept: 28 Juli 2021; Dipublish: 02 Agustus 2021 \\ *Corresponding author: E-mail: dnpsari26@gmail.com
}

\begin{abstract}
Abstrak
Penelitian ini bertujuan untuk melihat hubungan antara pola asuh demokratis dengan perilaku asertif pada remaja di Fakultas Psikologi Universitas Medan Area. Tipe penelitian yang digunakan adalah kuantitatif korelasional dengan melibatkan sampel penelitian berjumlah 78 orang remaja yang diambil dengan teknik purposive sampling dengan kriteria remaja berusia 18-19 tahun, di asuh dengan pola asuh demokratis. Alat ukur yang digunakan yakni skala pola asuh demokratis yang disusun berdasarkan ciri-ciri menurut Casmini (2007), dan skala perilaku asertif berdasarkan aspek-aspek menurut Alberti \& Emmons (2002). Hasil analisis menggunakan product moment diperoleh nilai koefisien kolerasinya 0,709 dengan signifikansi $p=0,000<0,05$. Hipotesis dari penelitian ini diterima artinya ada hubungan positif antara pola asuh demokratis dan perilaku asertif pada remaja di Fakultas Psikologi Universitas Medan Area. Dengan bobot sumbangan 50,30\%. Hasil ini diketahui dengan melihat mean hipotetik perilaku asertif 100 dan pola asuh demokratis 75, kemudian mean empirik untuk perilaku asertif 119,256 dan pola asuh demokratis 87,153. Sedangkan penelitian terdahulu Anung (2016) mengenai pengaruh pola asuh demokratis terhadap perilaku asertif pada remaja didapat data bahwa pola asuh demokratis memiliki pengaruh terhadap perilaku asertif remaja $r^{2}=0.632 ; p=0.000 ; p<0.005$ maka pola asuh demokratis orang tua memiliki pengaruh yang signifikan sebesar 63,2\% sedangkan sisanya dipengaruhi oleh factor yang lainnya.
\end{abstract}

Kata Kunci: Pola Asuh Demokratis; Perilaku Asertif; Remaja

\begin{abstract}
This study aims to examine the relationship between democratic parenting patterns with assertive behavior in adolescents at the Faculty of Psychology, University of Medan Area. The type of research used is quantitative correlation by involving a research sample of 78 adolescents taken by purposive sampling technique with the criteria of adolescents aged 18-19 years, fostered with democratic parenting. The measuring instrument used is the scale of democratic parenting which is based on characteristics according to Casmini (2007), and the scale of assertive behavior based on aspects according to Alberti \& Emmons (2002). The results of the analysis using the product moment obtained a correlation coefficient of 0.709 with a significance of $p=0.000<0.05$. The hypothesis of this study is accepted, meaning that there is a positive relationship between democratic parenting and assertive behavior in adolescents at the Faculty of Psychology, University of Medan Area. With a contribution weight of 50.30\%. These results are known by looking at the hypothetical mean of assertive behavior 100 and democratic parenting 75, then the empirical mean for assertive behavior is 119.256 and democratic parenting is 87.153. Meanwhile, Anung's previous research (2016) regarding the effect of democratic parenting on assertive behavior in adolescents obtained data that democratic parenting has an influence on adolescent assertive behavior $r^{2}=0.632 ; p=0.000 ; p<0.005$ then democratic parenting of parents has a significant effect of $63.2 \%$ while the rest is influenced by other factors.
\end{abstract}

Keywords : Democratic Parenting; Assertive Behavior; Adolescents

DOI: https://doi.org/10.51849/j-p3k.v2i2.111

Rekomendasi mensitasi :

Sari, D.P., Istiana, \& Wahyuni, N.S.. (2021), Hubungan Pola Asuh Demokratis Dengan Perilaku Asertif Pada Remaja. Jurnal Penelitian Pendidikan, Psikologi dan Kesehatan (J-P3K), 2 (2): 148-157. 


\section{PENDAHULUAN}

Setiap individu memiliki tugas dalam tiap perkembangannya dan kehidupan sesuai rentang usia. Secara psikologis, individu memiliki tujuan atas tugas dalam perkembangan yaitu pertama, sebagai petunjuk bagi individu untuk mengetahui apa yang diharapkan masyarakat dari mereka pada usia-usia tertentu. Kedua, dalam memberi motivasi kepada setiap individu untuk melakukan apa yang diharapkan dari mereka oleh kelompok sosial pada usia tertentu sepanjang kehidupan mereka. Ketiga, menunjukkan kepada setiap individu tentang apa yang akan mereka hadapi dan tindakan apa yang diharapkan dari mereka kalau sampai pada tingkat perkembangan berikutnya (Hurlock, 2010).

Menurut Hurlock (2010) remaja memiliki tugas perkembangan, salah satunya seperti mampu menerima keadaan fisiknya, mampu menerima dan memahami peran seks usia dewasa, mencapai kemandirian ekonomi, mampu mencapai kemandirian emosional serta mampu membina hubungan baik (berinteraksi) dengan anggota kelompok yang berlainan jenis, mengembangkan konsep dan keterampilan intelektual yang diperlukan untuk berperan sebagai anggota masyarakat, memahami dan menginternalisasikan nilai-nilai orang dewasa dan orang tua, mengembangkan perilaku tanggung jawab sosial yang diperlukan untuk memasuki dunia dewasa, mempersiapkan diri untuk memasuki usia perkawinan, dan memahami serta mempersiapkan berbagai tanggung jawab kehidupan keluarga.
Remaja sebetulnya tidak mempunyai tempat yang jelas. Mereka sudah tidak termasuk golongan anak-anak, tetapi belum juga dapat diterima secara penuh untuk masuk ke golongan orang dewasa. Remaja ada diantara anak dan orang dewasa. Oleh karena itu, remaja seringkali dikenal dengan fase "mencari jati diri" atau fase "topan dan badai". Remaja masih belum mampu menguasai dan memfungsikan secara maksimal fungsi fisik maupun psikisnya (Monks \& Rahayu, 2018).

Selain perubahan yang terjadi di dalam diri remaja, terdapat pula perubahan dalam lingkungan seperti sikap orang tua atau anggota keluarga lain, guru, teman sebaya, maupun masyarakat pada umumnya. Remaja mampu memanfaatkan tingkah laku yang dianggap pantas atau sesuai bagi orang-orang seusianya. Remaja perlu memiliki kemampuan berperilaku asertif dalam proses menjalin hubungan yang baik.

Menurut Albert \& Emmons (dalam Setiono \& Pramadi, 2005) perilaku asertif adalah bentuk keterampilan sosial yang tepat untuk berbagai situasi sosial. Sedangkan menurut Khan (2012) juga mengemukakan bahwa perilaku asertif adalah suatu kemampuan untuk menyampaikan apa yang diinginkan, dipikirkan dan dirasakannya kepada orang lain serta mampu menjaga haknya dan hak orang lain. Individu yang memiliki perilaku asertif maka individu tersebut merasa percaya diri, terbuka, jujur dan merasa dihormati. Untuk menjalin hubungan interpersonal yang baik, seseorang membutuhkan kemampuan berperilaku asertif. Individu yang sering berperilaku tidak asertif akan merasa 
tidak nyaman apabila hal ini terjadi terusmenerus akan menimbulkan konflik.

Perilaku pergaulan remaja dalam membina hubungan kerap menjadi sesuatu hal yang dipertanyakan, ini sering terjadi dimana remaja masih bersifat labil dalam tindakan, sering juga memunculkan emosi yang tidak terkontrol yang menyebabkan terjadinya kesalah pahaman antara individu yang satu dengan yang lainnya. Sebaliknya seseorang bisa menahan diri dan dapat mengemukakan pendapatnya tanpa menimbulkan kesan yang tidak baik. Perilaku ini sering disebut dengan perilaku asertif. Perilaku asertif adalah kemampuan individu mengemukakan pendapat, menyampaikan perasaan serta kebutuhan secara terbuka, tanpa rasa cemas, dan dengan tetap menghormati orang lain (Alberti \& Emmons, 2002). Individu yang kurang asertif memiliki kecenderungan menjadi kurang percaya diri saat berada di depan umum (Ames, Lee \& Wazlawek, 2017; Fox \& Boulton, 2005).

Menurut Corey (dalam Sutrisnawaty, 2015) mengatakan ada beberapa ciri individu yang perilaku asertif yaitu, mampu mengungkapkan kemarahan dan perasaan tersinggung, tidak menunjukkan kesopanan yang berlebihan dan tidak selalu mendorong orang lain untuk mendahuluinya, tidak mengalami kesulitan untuk mengungkapkan afeksi dan respon-respon lainnya.Sedangkan menurut (Alberti \& Emmons, 2002) mengungkapkan bahwa ciri-ciri perilaku kurang asertif diantaranya remaja cenderung menyangkali ekpresi diri, tidak menunjukkan perasaan sesungguhnya, cemas dan mengikuti pilihan orang lain yang memilih.

Selain faktor penyebab dari hasil penelitian, ditemukan pula dampak dari perilaku asertif. Perilaku asertif berdampak pada penurunan kecemasan social seseorang (Misnani, 2016). Selain pengaruh positif dari perilaku asertif, terdapat pula dampak yang terjadi akibat kurangnya perilaku asertif. Pada penelitian tersebut dijelaskan bahwa individu yang kurang asertif cenderung pemalu, tertutup, dan tidak dapat menyatakan keinginannya. Orang yang kurang asertif, kurang dapat mengungkapkan keinginan dan perasaannya sehingga kurang mendapat dukungan sosial serta masukan dari orang lain, kurang memiliki sumber daya manusia yang dapat diandalkan untuk mengatasi masalah ataupun stress yang sedang dihadapinya, cenderung kurang kuat pendiriannya sehingga mudah terjerumus pada hal-hal yang negative, dan dapat berdampak pada kecenderungan untuk menyanggah suatu permasalah (Sriyanto et al., 2014). Hal tersebut dapat memicu dampak negatif lain yang menimbulkan kerugian bagi diri sendiri maupun orang-orang sekitarnya.

Oleh karena itu, UMA memiliki banyak fakultas sehingga peneliti lebih memfokuskan pada fakultas psikologi, karena di fakultas psikologi dituntut untuk memiliki komunikasi yang baik, karena harus bertemu dan berinteraksi degan orang lain. Jadi otomatis kalausudah diberi bekaluntuk berkomunikasi yang baik, seharusnya mahasiswa psikologi lebih asertif, ternyata dari fenomena yang terlihat di lapangan masih ada mahasiswa yang 
kurang berperilaku asertif. Salah satunya mahasiswa dituntut untuk mengembangkan pengetahuan secara optimal serta mampu melakukan penguasaan ilmu pengetahuan agar kelak dimasa mendatang mereka dapat berpartisipasi aktif dalam pembangunan dan menjadi sumber daya manusia yang berguna bagi bangsa dan Negara (Broto, 2009).

Oleh karena itu, seorang mahasiswa harus sadar akan tugas yang diembannya dan perannya yang begitu penting bagi bangsa. Namun, tidak sedikit mahasiswa yang tidak mampu untuk bersikap asertif. Sebagai contoh, mahasiswa yang sedang diberikan tugas kelompok namun tidak menjalankan tugasnya dengan baik didalam kelompok atau bahkan ada yang dengan sengaja tidak memberikan kontribusi dalam kelompok, untuk melatih sikap asertif terhadap mahasiswa faktultas Psikologi Universitas Medan Area mahasiswa diberikan berbagai macam metode belajar untuk mampu menempatkan dirinya pada keadaan yang tepat.

Fenomena yang terjadi kepada remaja menunjukkan perilaku asertif dapat terjadi di berbagai konteks salah satunya di lingkungan perkampusan. Perilaku tersebut lebih sering terjadi pada remaja yang memiliki teman dekat (geng). Dalam lingkungan perkuliahan, komunikasi tersebut tampak dalam berbagai kegiatan yang dilakukan secara bersama-sama antara lain ketika makan dikantin, belajar dikelas dan bermain. Dalam lingkungan, remaja melakukan perilaku asertif yang khas dengan teman sebayanya. Contohnya antara lain mereka menggunakan kata-kata yang umum untuk menjelaskan kata-kata yang khusus karena mereka malu untuk mengungkapkan sesuatu yang membuat teman sebayanya tersinggung, seperti seorang remaja yang sedang merokok mengatakan kepada temannya dia untuk menenangkan pikiran atau remaja yang hamil di luar nikah mengatakan hal tersebut dengan kata kecelakaan (Rukiah, 2010).

Tidak hanya itu, remaja lebih banyak menggunakan perasaan ketika menanggapi suatu masalah sehingga ketika memberi umpan balik mereka lebih menjaga perasaan lawan bicara mereka (Guntur, 2008). Di sisi lain, perilaku kurang asertif juga dapat terjadi di lingkungan kampus. Perilaku asertif di sini diartikan remaja kurang mampu mengungkapkan pikiran, pendapat dan perasaannya kepada teman sebaya. Ketika remaja melakukan hal tersebut maka remaja tersebut cenderung mengikuti keinginan teman-temannyayang dapat menimbulkan efek negative. Remaja cenderung mudah terpengaruh karena mereka kurang mempunyai peluang untuk mengungkapkan pendapatnya.

Ada beberapa factor yang mempengaruhi asertif antara lain pola asuh, umur, kebudayaan dan jenis kelamin (Santosa, 1999). Menurut Baumrind pola asuh orang tua adalah segala bentuk dan interaksi yang terjadi antara anak dan orang tua yang merupakan pola pengasuhan tertentu dalam keluarga yang akan memberikan pengaruh terhadap perkembangan kepribadian anak (dalam Marini dan Andriani, 2005). Setiap orang tua memiliki pola pengasuhan yang berbeda-beda. Menurut (Santrock, 2012) setiap keluarga menerapkan pola 
pengasuhan dengan mengkombinasikan berbagai macam pola tetapi ada satu pola pengasuhan tertentu yang lebih dominan yang diterapkan oleh orang tua kepada anaknya. Menurut Papalia, (2014) pola asuh orang tua dibedakan menjadi tiga macam yaitu pola asuh otoriter, pola asuh permisif dan pola asuh demokratis.

Dijelaskan pada pola asuh otoriter, ditandai dengan adanya aturan-aturan yang kaku dari orang-tua, cenderung untuk menentukan peraturan tanpa berdiskusi dengan anak-anak mereka terlebih dahulu. Pada pola asuh permisif yang sedikit terlibat dengan anak dan tidak menyadari apa yang dilakukan anak. Selanjutnya pada pola asuh demokratis, orang-tua lebih mendorong kemandirian pada batasan tertentu, hangat dan penuh kasih sayang sehingga anak mampu berkompeten secara sosial, mampu bergantung pada diri sendiri bertanggung jawab secara sosial.

Pola asuh orang tua yang memberikan pengaruh pada asertif seorang remaja adalah pola asuh demokratis. Pola asuh demokratis menurut Santrock, (2002) adalah adanya tuntutan dari orang tua namun tetap ada komunikasi yang terbuka antara orang tua dan anak serta adanya kehangatan dari orang tua pada anak. Berk (dalam Marini dan Andriani, 2005) juga menegaskan bahwa orang tua yang menerapkan pola asuh demokratis juga berperilaku asertif terhadap keinginan anak-anaknya sehingga dengan sendirinya orang tua memberikan model terhadap pertumbuhan perilaku asertif.

Ketika remaja berada di luar rumah dan melakukan kegiatan dengan temantemannya seperti bermain dan belajar.
Ketika dilingkungan kampus, remaja menganggap teman-temannya merupakan orang yang penting saat itu. Pada saat mereka menganggap temannya penting, pengaruh positif maupun negative yang diberikan teman-temannya dapat dengan mudah mereka terima meskipun pada saat mereka tinggal dirumah, mereka mendapatkan pola asuh demokratis.

Pada saat tinggal di rumah, remaja mendapat kesempatan dari orang tua mengungkapkan pendapatnya meskipun berbeda tetapi bisa jadi di kampus remaja tersebut tidak mampu mengungkapkan pendapatnya. Hal tersebut bisa terjadi karena mereka ingin teman-teman menyukainya dan mendapatkan teman banyak. Mereka dapat menyingkirkan pendapatnya dan mengikuti perilaku temannya meskipun tidak sesuai dengan dirinya karena mereka ingin temantemannya menyukainya dan tidak menjauhinnya.

Menurut Baumrind (Casmini, 2007) terdapat juga ciri-ciri pola asuh orang tua demokratis meliputi, tegas namun tetap hangat, mengatur standar agar dapat melaksanakan dan memberi harapan, konsisten terhadap kebutuhan dan kemampuan anak, memberi kesempatan anak untuk berkembang otonomi dan mampu mengarahkan diri, menghadapi anak secara rasional dan memberi dorongan dalam diskusi keluarga.

Penelitian ini dilakukan pada remaja yang kurang berperilaku asertif di Universitas Medan Area karena disana beberapa remajakurang berperilaku asertif seperti yang di sampaikan oleh beberapa remaja berikut ini:

"Di lingkungan pertemanan saya sulit bergaul dan kurang mudah berbaur 
dengan teman-teman saya. Jika ada sesuatu hal yang tidak sesuai dengan keinginan saya, saya kurang berani untuk mengatakannya langsung kepada orangnya langsung paling hanya bisa dari perantaraan teman saya saja, sebab saya takut dia tersinggung dan menyakiti perasaannya ketika saya mengatakan pendapat saya secara langsung".. (Wawancara personal, 30 September 2019).

Dengan pemaparan kutipan wawancara diatas, bahwa subjek mengaku ia tidak mudah bergaul dan berbaur dalam lingkungan pertemanan, jadi kalau ada sesuatu hal yang tidak suka maka ia hanya bisa menyampaikan perantaraannya lewat temannya dan ia tidak berani langsung mengatakanya.

Disamping itu, subjek lain mengungkapkan hal yang berbeda ketika diwawancarai seperti kutipan wawancara berikut ini. Subjek mengaku ketika kerja kelompok lebih mengikuti ide-ide yang keluar dari pikiran temannya tanpa mau mengeluarkan ide dari ia sendiri dan subjek juga tidak mampu untuk menolak dengan alasan takut tersinggung.

"kalau sedang kerja kelompok, saya sulit untuk mengungkapkan argument serta pikiran saya, saya selalu mengikuti ide-ide apa yang diberikan dengan teman saya sebab saya tidak mampu menyangkal atau menolak sesuatu kepada teman saya, lebih ke diam si kak karna saya takutapa yang saya berikan itu tidak ditanggapi bahkan lari dari topic pembahasan". (Wawancara personal, 30 September 2019).

Berdasarkan uraian diatas dan wawancara yang telah dilakukan, peneliti tertarik untuk meneliti mengenai
Hubungan Pola Asuh Demokratis dengan Perilaku Asertif pada Remaja di Fakultas Psikologi Universitas Medan.

\section{METODE PENELITIAN}

Penelitian ini adalah penelitian kuantitatif yaitu penelitian yang menggunakan aspek pengukuran, penghitungan, rumus, dan kepastian dalam proses pengerjaannya (Musianto, 2002). Tipe penelitian ini adalah penelitian kuantitatif korelasional yakni penelitian yang bertujuan untuk mengetahui hubungan suatu variabel dengan variabel-variabel lain (Hamdi \& Baharuddin, 2014). Tipe penelitian tersebut dianggap cocok karena peneliti ingin melihat hubungan pola asuh demokratis dengan perilaku asertif.

Definisi operasional masing-masing dari variable prnrlitian sebagai berikut: Pola asuh demokratis adalah sebagai pola asuh yang memprioritaskan kepentingan anak, akan tetapi tidak ragu-ragu mengendalikan meraka. Orang tua dengan pola asuh ini bersikap rasional, selalu mendasari tindakannya pada rasio atau pemikiran-pemikiran. Orang tua tipe ini juga bersikap realistis terhadap kemampuan anak, tidak berharap yang berlebihan yang melampaui kemampuan anak. Casmini (2007) memaparkan ciriciri pola asuh demokratis meliputi, tegas namun tetap hangat, mengatur standar agar dapat melaksanakan dan memberi harapan, konsisten terhadap kebutuhan dan kemampuan anak, memberi kesempatan anak untuk berkembang otonomi dan mampu mengarahkan diri, namun anak harus memiliki tanggung jawab terhadap tingkah lakunya, enghadapi anak secara rasional, orientasi 
pada masalah-masalah, memberi dorongan dalam diskusi keluarga dan menjelaskan disiplin yang mereka berikan. Perilaku Asertif: Perilaku asertif adalah kemampuan individu mengekspresikan perasaan, pendapat serta kebutuhan dirinya secara terbuka, jujur dan tanpa rasa cemas dengan tetap menghormati orang lain. Asertif dilakukan melalui komunikasi verbal dan nonverbal, yaitu melalui bahasa, ekspresi wajah, dan bahasa tubuh. Aspek asertif menurut Alberti \& Emmons (2002), yaitu mempromosikan kesetaraan dalam hubungan manusia, bertindak menurut kepentingan sendiri, mampu membela diri sendiri, mengekspresikan perasaan secara jujur dan nyaman, mempertahankan hakhak pribadi, menghargai hak-hak orang lain

Dalam hal ini peneliti memperoleh data remaja yang berasal dari pola asuh demokratis dari hasil screening yang peneliti lakukan. Populasi adalah wilayah generalisasi yang terdiri atas objek/subjek yang mempunyai kualitas dan karakteristik tertentu yang ditetapkan oleh peneliti. Dari pengertian tersebut, maka dapat disimpulkan bahwa populasi merupakan subjek penelitian dimana individu yang akan dikenai perilaku atau dapat dikatakan sebagai keseluruhan objek penelitian yang akan diteliti. Adapun populasi seluruh remaja fakultas psikologi Universitas Medan Area 460 remaja stambuk/angkatan 2019. Teknik pengambilan sampel dalam penelitian ini adalah purposive sampling. Purposive sampling adalah teknik pengambilan sampel sumber data dengan pertimbangan tertentu (Sugiyono, 2016). Alasan mengambil purposive sampling karena menurut Sugiyono (2016) adalah karena tidak semua sample memiliki criteria yang sesuai dengan fenomena yang diteliti. Oleh karena itu, penulis memilih teknik purposive sampling yang menetapkan pertimbangan-pertimbangan atau criteria-kriteria tertentu yang harus dipenuhi oleh sample-sample yang digunakan dalam penelitian. Sampel yang diambil dalam penelitian ini berdasarkan screening yang telah dilakukan yaitu sebanyak 78 remaja.

Metode analisis data yang digunakan untuk menguji hipotesis penelitian kuantitatif tentang Hubungan Pola Asuh Demokratis dengan Perilaku Asertif Pada Remaja di Fakultas Psikologi Universitas Medan Area adalah metode analisis data yang digunakan pada penelitian ini adalah product moment dari Karl Pearson. Alasan digunakanya teknik korelasi ini karena pada penelitian ini memiliki tujuan untuk melihat hubungan antara suatu variabel bebas (pola asuh demokratis) dengan satu variabel terikat (perilaku asertif).

\section{HASIL DAN PEMBAHASAN}

Berdasarkan hasil analisis dengan Metode Analisis Korelasi Product Moment, diketahui bahwa terdapat hubungan positif yang signifikan antara pola asuh demokratis dengan perilaku asertif, dimana $r_{x y}=0,709 ; p=0.000<0,05$. Artinya jika polaasuh demokratis tinggi, maka perilaku asertif semakin tinggi.

\begin{tabular}{llllll}
\multicolumn{5}{l}{ Tabel 1. Hasil Analisis Uji Hopotesis Korelasi } \\
\hline Statistik & $\begin{array}{l}\text { Koefisien } \\
\left(\mathbf{r}_{\mathrm{xy}}\right)\end{array}$ & $\begin{array}{l}\text { Koef. } \\
\text { Det. }\left(\mathbf{r}^{2}\right)\end{array}$ & $\mathbf{P}$ & BE\% & Ket \\
\hline $\mathrm{X}-\mathrm{Y}$ & 0,709 & 0,000 & 0,503 & $50,30 \%$ & Signifikan \\
\hline
\end{tabular}

Berdasarkan tabel diatas maka dapat disimpulkan bahwa koefisien determinan $\left(r^{2}\right)$ dari hubungan antara variabel bebas 
$\mathrm{X}$ dan variabel terikat $\mathrm{Y}$ adalah $\mathrm{r}^{2}=0,000$. Ini menunjukkan bahwa pola asuh demokratis berdistribusi terhadap perilaku asertif sebesar 50,30\%.

Tabel 2. Hasil Perhitungan Mean Hipotetik dan Empirik

\begin{tabular}{|c|c|c|c|c|}
\hline \multirow{2}{*}{ Variabel } & \multirow{2}{*}{ SB / SD } & \multicolumn{2}{|c|}{ Nilai Rata-Rata } & \multirow{2}{*}{ Keterangan } \\
\hline & & Hipotetik & Empirik & \\
\hline $\begin{array}{l}\text { Pola asuh } \\
\text { demokratis }\end{array}$ & 10.589 & 62,50 & 87,153 & Tinggi \\
\hline Perilaku Asertif & 18,584 & 100,00 & 119,256 & Tinggi \\
\hline
\end{tabular}

Dalam upaya mengetahui kondisi pola asuh demokratis dan perilaku asertif, maka perlu dibandingkan antara mean/nilai rata-rata empirik dengan mean/nilai rata-rata hipotetik dengan memperhatikan besarnya bilangan SB atau SD dari masing-masing variabel. Untuk variabel pola asuh demokratis nilai SB atau SD nya adalah 10,589 , sedangkan untuk variabel perilaku asertif adalah 18,584. Gambaran selengkapnya mengenai perbandingan mean/nilai ratarata hipotetik dengan mean/nilai rata-rata empiric dapat dilihat pada table di bawah ini.

Dari besarnya bilangan SB atau SD tersebut, maka untuk variabel pola asuh demokratis, apabila mean/nilai rata-rata hipotetik < mean/nilai rata-rata empirik, dimana selisihnya melebihi bilangan satu SB/SD, maka dinyatakan bahwa pola asuh demokratis individu positif dan apabila mean/nilai rata-rata hipotetik > mean/nilai rata-rata empirik, dimana selisihnya melebihi bilangan satu Simpangan Baku/Standar Deviasi, maka dinyatakan bahwa pola asuh demokratis individu negatif.

Selanjutnya untuk variabel perilaku asertif, apabila mean/nilai rata-rata hipotetik < mean/nilai rata-rata empirik, dimana selisihnya melebihi bilangan satu
SB/SD, maka dinyatakan bahwa perilaku asertif individu tergolong tinggi dan apabila mean/nilai rata-rata hipotetik > mean/nilai rata-rata empirik, dimana selisihnya melebihi bilangan satu Simpangan Baku/Standar Deviasi, maka dinyatakan bahwa individu memiliki Perilaku Asertif yang rendah.

Berdasarkan perbandingan dari kedua mean diatas (mean hipotetik dan masa empirik) dapat diketahui secara umum bahwa subjek penelitian ini memiliki pola asuh demokratis yang negative dan perilaku asertif yang rendah. Perilaku asertif tergolong rendah dapat terjadi karena beberapa alasan, alasan pertama yaitu pengaruh dari lingkungan pertemanan, di Universitas Medan Area banyak remaja yang berasal dari keluarga yang diasuh dengan pola asuh demokratis, sehingga membuat mereka tidak merasa sendiri dan merasa sederajat dengan yang lainnya, sehingga membuat mereka lebih dekat dan nyaman, hal ini dapat membuat perilaku asertif remaja lebih baik karena teman ikut mempengaruhi atau menguatkan perilaku asertif remaja. Dalam penelitian ini, peneliti tidak meneliti mengenai pola asuh demokratis terjadi, sehingga melihat hasil perilaku asertif yang menunjukkan kategori sedang bisa saja terjadi karena pengaruh tersebut yang tidak peneliti ketahui. Alasan terakhir yaitu beberapa remaja kurang terbuka atau jujur dalam menjawab butirbutir skala tersebut. Hal ini dapat diketahui karena pada saat wawancara singkat (sebelum penelitian dilakukan) peneliti memberi pertanyaan mengenai perilaku asertif yang kurang lebih maknanya sama seperti yang terdapat dalam skala dan didapat hasil bahwa 
semua remaja yang diwawancara menunjukkan perilaku asertif yang rendah sementara saat penelitian dilakukan (penyebaran skala) remaja tersebut tidak menjawab seperti saat diwawancara sehingga menyebabkan hasil olah data tidak sama seperti fenomena yang terlihat.

\section{SIMPULAN}

Berdasarkan hasil penelitian yang telah dilakukan dalam penelitian ini, maka dapat disimpulkan hal-hal sebagai berikut:

Berdasarkan hasil analisis dengan Metode Korelasi Product Moment dari Pearson, diketahui bahwa terdapat hubungan positif antara pola asuh demokratis dengan perilaku asertif pada remaja dari fakultas psikologi di Universitas Medan Area. Dapat di lihat dari Koefisien $r_{x y=0,709}$ dengan $p<0,05$. Maka dapat diartikan semakin tinggi/positif pola asuh demokratis maka semakin tinggi perilaku asertif dan sebaliknya semakin rendah/negative pola asuh demokratis maka semakin rendah perilaku asertifnya.

Sumbangan yang di berikan oleh pola asuh demokratissebesar $r^{2}=0,503$. Ini menunjukkan bahwa perilaku asertif dibentuk oleh pola asuh demokratis sebesar $50,30 \%$ dari presentase sumbangan ini maka terlihat masih terdapat 49,7\% pengaruh dari faktor lain.

Mean Hipotetik yang didapatkan dari 36 butir pernyataan untuk mengungkapkan pola asuh demokratis adalah 30 dengan mean empirik pola asuh demokratis sebesar 75. Mean Hipotetik yang didapatkan dari 58 butir pernyataan untuk mengungkapkan perilaku asertif adalah 40 dengan mean empirik perilaku asertif sebesar 100,00.

\section{DAFTAR PUSTAKA}

Alberti, R.. \& Emmons, M. (2002). Your Perfect Right: Hidup Lebih Bahagia dengan Mengungkapkan Hak. Jakarta: PT. Elex Media Komputindo.

Ali, M. \& Asrori, M. (2011). Psikologi Remaja Perkembangan Peserta Didik. Jakarta: PT. Bumi Aksarat.

Ames, D., Lee, A., \& Wazlawek, A. (2017). Interpersonal Assertiveness: Inside the Balancing. Soc Personal Psychol Compass, 116.

Anindyajati, M. \& Karim, C. M. (2004). Peran Harga Diri Terhadap Asertivitas Remaja Penyalaguna Narkoba (Penelitian Pada Remaja Penyalagunaan Narkoba di TempatTempat Rehabilitas). Jurnal Psikologi.

Ardiyanti, N. (2010). Hubungan Antara Asertivitas Dengan Kecenderungan Mengalami Kekerasan Emosional pada Perempuan Yang Berpacaran.Skripsi. Universitas Muhammadiyah Surakarta.

Arikunto, S. (2010). Prosedur Penelitian Suatu Pendekatan Praktik. Jakarta: Rineka Cipta.

Casmini. (2007). Emotional Parenting: Dasar-Dasar Pengasuhan Kecerdasan Emosional Anak. Yogyakarta: Macmillan.

Conny, R. Semiawan. (2009). Penerapan Pembelajaran Pada Anak. Jakarta: Indeks.

Cristine, D. (2011). Kemandirian Mengerjakan Tugas Sekolah Ditinjau dari Pola Asuh Demokratis Orang Tua.Skripsi. Universitas Katolik Soegijapranata: Semarang.

Desmita. (2011). Psikologi Perkembangan Peserta Didik. Bandung: PT. Remaja Rosdakarya.

Drew, Edwards. (2006). Ketika Anak Sulit Diatur. Bandung: PT. Mizan Pustaka.

Gunarsa, S. D., \& Gunarsa, Y. S. (2008). Psikologi Perkembangan Anak dan Remaja. Jakarta: PT. BPK Gunung Mulia.

Hamdi, A. S.\& Baharuddin. (2014). Metode Penelitian Kuantitatif Aplikasi Dalam Pendidikan. Yogyakarta: Deepublish.

Hurlock, E. B. (2010). Psikologi Perkembangan: Suatu Pendekatan Sepanjang Rentang Kehidupan. Jakarta: Erlangga.

Jonatha, Sarwono. (2006). Metode Penelitian Kuantitatif dan Kualitatif. Yogyakarta: Graha Ilmu.

Khan, R. I. (2012). Perilaku Asertif, Harga Diri dan Kecenderungan Depresi. Jurnal Psikologi Indonesia , 1 (2), 143-154.

Marini, L. \& Andriani, E. (2005). Perbedaan Asertivitas Remaja Ditinjau dari Pola Asuh Orang Tua. Jurnal Psikologi , 46-53.

Miasari, A. (2012). Hubungan Antara Komunikasi Positif Dalam Keluarga Dengan Asertivitas 
Pada Siswa SMPN 2 Depok. Yogyakarta: Emphaty.

Misnani, J. (2016). Hubungan Perilaku Asertif dan Kesepian dengan Kecemasan Sosial Korban Bullying Pada Siswa SMPN 27 Samarinda. Psikoborneo, 793-802.

A. M. P, F. J. Monks, Knoers \& Rahayu Siti. (2018). Psikologi Perkembangan: Pengantar dalam Berbagai Bagiannya. Yogyakarta: Gadja Mada University Press.

Musianto, L. K. (2002). Perbedaan Pendekatan Kuantitatif Dengan Pendekatan Kualitatif Dalam Metode Penelitian. Jurnal Manajemen \& Kewirausahaan , 123-136.

Nurmala, I, dkk. (2020). Mewujudkan Remaja Sehat Fisik, Mental dan Sosial (Model Intervensi Health Educator for Youth). Surabaya: Airlangga University Press.

Papalia, E. D.\& Feldman, R. T. (2014). Menyelami Perkembangan Manusia: Experience Human Development. Jakarta: Salemba Humanika.

Paramitasari. (2011). Hubungan Antara Perilaku Asertif dan Tingkat Stress Kerja Pada Karyawan.Skripsi. Fakultas Psikologi Universitas Sanata Dharma: Yogyakarta.

Pourjali, F. \& Zarnaghash, M. (2010). Relationship Between Assertiveness and the Power of Saying No With Mental Health Among Undergraduate Student. Procedia Social and Behavioral Sciences , 137-141.

Pratiwi, W. E. (2015). Pengaruh Budaya Jawa dan Harga Diri Terhadap Asertivitas Pada Remaja Siswa Kelas X di SMAN 3 Ponorogo. Jurnal Psikologi , 348-357.

Putri, G.G., D, P.A., \& Najahi, S, (2013). Perbedaan Sels-Acceptance Pada Anak Panti Asuhan Ditinjau Dari Segi Usia. Procceding pesat (Psikologi, Ekonomi, Sastra, Arsitektur \& Teknik Sipil), 5, P11-P16.

Prayitno. (2004). Layanan Bimbingan dan Konseling. Padang: BK. FIP.

Ratna. (2013). Teknik-Teknik Konseling. Yogyakarta: Deepublish.

Rukiah, E. (2010). Ragam Bahasa Remaja Puteri dalam Percakapan Informal Dikampus UPI Tasikmalaya. Jurnal Saung Guru , 79-85.

Santosa, J. (1999). Peran Orang Tua Dalam Mengajarkan Asertivitas pada Remaja. Psychological Journal , 83-91.

Santrock, J. W. (2003). Adolescence. Jakarta: Erlangga.

Santrock, J. W. (2007). Life Span Development: Perkembangan Masa Hidup (jilid 2). Jakarta: PT. Erlangga.

Santrock, J. W. (2002). Perkembangan Masa Hidup. Jakarta: Erlangga.

Setiono \& Pramadi. (2005). Pelatihan Assertivitas dan Peningkatan Perilaku Asertif pada
Siswi-Siswi SMP. Jurnal Psikologi , Vol.20 No. 2 (149-168).

Hanum. Sri. (2013). Hubungan Antara Pola Asuh Demokratis Dengan Perilaku Asertif Pada SMAN 3 Medan. Medan: Universitas Medan Area.

Sriyanto., Abdulkarim, A., Zainul, A., \& Maryani, E. (2014). Perilaku Asertif dan Kecenderungan Kenakalan Remaja Berdasarkan Pola Asuh dan Peran Media Massa. Jurnal Psikologi, 74-88.

Sugiyono. (2016). Metode Penelitian Kuantitatif, kualitatif dan $R$ \& D. Bandung: PT. Alfabet.

Nano Sunartyo. (2006). Membentuk Kecerdasan Anak Sejak Dini. Yogyakarta: Think.

Siswanto Dedy. (2020). Anak Di Persimpangan Perceraian (Menilik Pola Asuh Anak Korban Perceraian. Surabaya: PT Airlangga University Press.

Surbakti, E. B. (2009). Kenalilah Anak Remaja Anda. Jakarta: PT. Alex Media Komputindo.

Syaiful, B. D. (2014). Pola Asuh Orang Tua dan Komunikasi Dalam Keluarga. Jakarta: Rineka Cipta. 